\title{
Creative Work of Cultic Poets of Runet as a Subcultural Phenomenon
}

\author{
Tatiana A. Zolotova ${ }^{1}$ \\ ${ }^{1}$ Mari State University, Yoshkar-Ola, Russia \\ Correspondence: Tatiana A. Zolotova, Mari State University, Lenin Sq. 1, Yoshkar-Ola, 424000, Russia. Tel: \\ 7-960-094-1153. E-mail: zolotova_tatiana@mail.ru
}

Received: February 21, 2015 Accepted: March 15, 2015 Online Published: April 29, 2015

doi:10.5539/res.v7n8p286

URL: http://dx.doi.org/10.5539/res.v7n8p286

\begin{abstract}
The article is devoted to the verbal creative work of a cult Runet author Vera Polozkova. The article is based on the material of her early lyrics, presented in the first published book "Nepoemanie" (2008). The poems by Polozkova are considered in the context of youth subculture traditions. We identified such key components of the poet's worldview typical of modern youth subcultures as non-conformism, elitism, the overall searching orientation of her creative work (information and communication technologies, the need for finding like-minded people, love and faith in God), in regards to poetics the main features are extreme expression (metaphorization), urbanism (poetization of urban space), as well as an appeal to the genres of youth creative work, slang, ICT vocabulary and obscene language. The author of the article makes a conclusion that the bright expression of some typical characteristics of youth culture by Vera Polozkova makes her a popular poet and performer both on Runet and outside it (live performances). At the same time subcultural issues and poetics do not limit the variety of the writer's lyric themes and poetic means. Her early works continue wonderful traditions of Russian literature, heritage of Marina Tzvetaeva, Vladimir Mayakovsky, Joseph Brodsky and others.

The article also identifies and focuses on the essential features of the electronic (digital) literature and the possibility of considering it as a space in which a number of subcultural associations/communities exist.
\end{abstract}

Keywords: Runet, electronic literature, cult authors, Vera Polozkova, early creative work, subcultural worldview, non-conformism, elitism, urbanism

\section{Introduction}

Electronic (digital) literature - "is the literature, created and distributed via the Internet"for two decades (Chernyak, 2010). A considerable number of articles examining its nature and essence, genres, methods of creation and distribution have been published during this period of time. A special column devoted to electronic (digital) literature by Sergey Kozirenko appeared in "The New World" journal in 2000. However, there is no agreement on the issue and the term "network literature" is used in two meanings: 1) as a trend in literature and literary criticism in which texts are created and published on the Web (on the Internet); 2) as an association of writers, essay authors and critics who begin and continue working on the Web" (Desyaterik, 2014). At the same time the term in its first meaning (as a trend in literature and literary criticism) is quite ambiguous and has both a broad and a narrow meaning. For example, following Dmitry Manin's term, electronic (digital) literature in its broad sense is interpreted as any fiction text published on the Web (no matter if it belongs to the author working on the Web or out of it); electronic (digital) literature in its narrow sense is essentially considered as "a text published on the Web so that its transfer to the paper is associated with a significant loss" (Manin, 2014).

In terms of specific characteristics of electronic (digital) literature they mainly include hypertextuality, anonymity/ collective and dynamic creative work, as well as game character of an author's work (Manin, 2014).

Modern electronic (digital) literature is often compared with "samizdat" (underground press in the USSR). Thus, according to the authors of the dictionary "Basic concepts of mass literature", "the Internet with its interactive features, variability, hypertextuality became the means of creation and distribution of alternative culture and a unique experimental platform for aspiring writers" (Chernyak \& Chernyak, 2010).

Indeed, upon a closer look, a network writer in comparison with writers and poets working with "paper" versions gets a range of advantages, "he may publish independently of various non-literary aspects"; "keep complete anonymity" and almost immediately after posting receive comments and reviews both from readers and 
professionals (literary specialists and critics) (Desyaterik, 2014).

At present websites Poezia.ru and Proza.ru have published about 25 million works of more than half a million authors. Meanwhile, poetic texts are much more popular than prose. The owner and the editor of these websites Dmitry Kravchuk said he was very interested in the fact that experts and reviewers on these websites were professional literary specialists and critics. These issues were discussed on a special TV program "Literary initiative: the triumph of graphomania or the victory over clans" ("In the Meantime" with Alexander Archangelsky) of the Russian channel Culture (Kravchuk, 2014). This article also focuses on the solution of this problem.

\section{Methods}

The article uses a complex approach to the study of the material, which includes descriptive and analytical, comparative historical and typological methods. Typical characteristics of Vera Polozkova's lyrics are identified with the help of descriptive and analytical methods. The comparative historical method allows to show traditions and innovations of the poet in the context of Russian poetry of XIX-XX centuries. The typological method sets general patterns of modern youth verbal creativity to which we may refer Polozkova's early works.

\section{Results and Discussion}

\subsection{Poetry Writing by Vera Polozkova in Modern Criticism}

Runet has already a list of popular writers and poets, who began their writing with network literature. V. D. Chernyak and M. A. Chernyak identify Dmitry Goryachev, Alex Exler, Max Frei, Ksenia Buksha and others. Vera Polozkova is one of the cult authors who have already got recognition in the network and outside it (pop, theatre, large publishing projects). In 2009 she was awarded a literary prize "Neformat", which caused a heated discussion first on the pages of "The Literary Newspaper" and then on the Internet. Such famous poets and critics as I. Panin, D. Bykov, L. Pirogov and others took part in the discussion.

Julia Idlis, the author of the well-known book Runet: the Created Idols (2010) gives the following testimonial on her pages: "Evgenia Vezhlyan, a critic and the leader of the literary saloon "Readers club" announced the discussion, titled "Isn't Polozkova a poet?" in her blog, as after awarding Polozkova a prize "Neformat" the question was of interest to the literary community. Some critics thought that Polozkova was an unfairly legitimatized poet, others considered that Polozkova legitimatized an obscure and indistinct award "Neformat" by her works and popularity. (Idlis, 2010).

The famous poet and critic Igor Panin was the first to provide a sharp critical article against the author. Giving credits for Vero4ka's talent and popularity (with her "army of fans") he, however, reproaches the poetess of the absence of individuality in his article titled The Doll, calling Polozkova "a glamorous young lady" and her creative work "poetry of soap operas", "trash literature", "literary second-hand" and predicts the fate of a thrown away doll (Panin, 2009).

Dmitriy Bykov supported Polozkova in his turn (Bykov, 2009). In his article "Little Vera" he writes that Polozkova needs objective and at the same time gentle criticism. Comparing Panin with Zoil he notices that the manner of the so-called "Pisarev's retelling" may ruin even the most talented poet. As regards Vera Polozkova he supposes that this is Vera who continues vivid traditions of Russian literature and moreover the way of further development of Russian poetry depends on this young lady. The critic is sure that "Polozkova-'par excellence'-is a true poet with her own theme" (Bykov, 2009). Despite some disadvantages (narcissism, recurrence etc.) she will eventually become "the first-rate poet, pride of Russian literature" (Bykov, 2009).

Ksenia Buksha's comments on Polozkova's personality and work are of great interest as well. She treats her on the one hand as a first-rate poet ("she can find rhymes and metaphors, compose drama of a poem"), on the other hand as an international brand-man, a hostage of her own image. In Buksha's opinion to be a success Polozkova should broad cultural and ideological outlook, "philozophism and thinking of thousands of different things" (Buksha, 2014).

It should be noted that analyzing Vera Polozkova's personality and creative work, critics marked some general characteristics such as narcissism ("she definitely doesn't suffer from modesty"-I. Panin), underlining her exclusiveness, powerful temper and some recurrence (dependence on other authors' samples).

A new approach to the study of Polozkova's poetry directly relevant to our observations is outlined in the article by Gutrina (2012). 


\subsection{Vera Polozkova's Work as a Sub-Cultural Phenomenon}

According to the researcher's point of view the poems of the analyzed book make the image of "a social circle", "it seems that the book is a kind of a password to identify for sure friends and foes" (Gutrina, 2012). Gutrina also considers that it is crucially important that "the possibility of coincidence" that is "co-existence with the world" gives "Polozkova" communication in her "social circle" on the basis of friendship (Gutrina, 2012, p. 179). It explains peculiar poetics of the book: encryptions in dates of poems, naming authors, numerous dedications, use of collective "we" and others. L. D. Gutrina was the first who sagely marked this kind of emphasis in Polozkova works. At the same time the Yekaterinburg researcher supposes that the replacement of a high purpose of creation oxygen (photosynthesis) for others with the creation it for herself and her social circle is an absolute and significant loss of young authors. From our point of view "treating mutual understanding between friends and "like -minded people" as the priority life value" (Gutrina, 2012) is an expression of one of the universal laws of the youth subculture. As opposed to "the culture of young people" created by marketing professionals, it is created for like-minded people and in general typologically close to the value attitudes of youth subcultures. (Nekludov, 2002, p. 6). Regarding Vera Polozkova, she expresses them in her early works quite decisively and emphatically. No wonder, her first nickname was "teenspirit".

To date the peculiarities of organization of subculture communities and ways of their participants' expression are quite thoroughly studied both in foreign and Russian cultural studies and sociology (for example, you may read a remarkable book by T. B. Shchepanskaya The System: texts and traditions of subculture) (Shchepanskaya, 2004). In the book the author describes in detail reasons and peculiarities of formation of the so-called teenagers exclusion zone ("antinorms"), search for friendly (uninvolved in official culture) ways of information (rock music, youth slang, specific genres of verbal creative work), the priority of spiritual and creative components, "marriage search", initiation rites to belong to "the core" of the community (getting a nickname, a personal symbol and a spiritual guide), "domestic dissent" (term by K. V. Chistov), attention to esoteric, formation of their own (often) eclectic philosophic system, urbanism as a characteristic feature of poetics and some others (depending on subculture/ community). As for the verbal aspect of creative work of subcultural communities it became the subject of thorough study in a number of our articles (Zolotova, Efimova, \& Sitnova, 2010; Zolotova, Efimova, 2014; Zolotova, 2014).

\subsubsection{Runet as the Main (Friendly) Communicative Channel}

Referring to Vera Polozkova's personality (see essay by Julia Idlis about Vera Polozkova), let us pay attention to a purposeful and insistent way of her setting up in Life Journal (one of the most popular web journals). It is worth while mentioning that in 1960-1980 (before the Web appeared), according to T. B. Shchepanskaya, alternative ways of information for youth subcultures were information search in western sources (for example, radio transmission "The Voice of America" and others), getting records of western musical groups, external attributes (hairstyles, clothes, style of behavior) which distinguished like-minded people, appropriate slang and others. Today a teenager gets all the information through the Internet; this is where he/she finds like-minded people. That's what young Vera Polozkova did.

Vera: My first nick, which I wanted to register, was "teenspirit". "Nirvana" has a song "Smells Like Teen Spirit. I used to sign letters in the same way, when I began "playing the Internet". As my mother says, "Vera plays the Internet." In short, "teenspirit" was occupied. My Life Journal nick was registered by my former best friend, who is one of quite strange characters in my life now. She gave me LJ "vero4ka", that was the way she would call me that time. I hated it at first, then I began working with it. She created the nick in December 2002, if I'm not mistaken. The first password was Tallinnrules, because she registered it being in Tallinn. I started to write something there. I had pure competitive spirit, because crowds of people read the girl's LJ. At that time 400 readers were quite a lot of people. It seemed to me she was a celebrity and I wanted to oppose her something.

Julia: "Oh my God, I'm here at last", said Vera in her first LJ vero4ka post dated January 3, 2003. I can 't make head or tail of the settings here, I'll examine them gradually. At least I have the right to share my opinion in this wonderful place and the rest is in the set." (here in after marked by T. Z.)

Vera: It was written in winter 2003 in the Internet café "Image.ru" in Mendeleevskaya Street. I went there like it was my job. I read posts of three people: Tryopa (who is Anya Zabolotnaya, she has LJ nick "blog" at the moment), her friend Lev Dolgachev, who is a photographer now and that time he was a pickuper and wrote how he picked-up chicks in different ways, though he was literally talented and could write. I also read posts of some mutual friends.

I don't remember that I felt happy, when my post was commented by 20 people. In the beginning I counted every time how many people added my posts to their news feeds. There even was a post, "There are about 60 people on 
the friends list, but only 5 make comments. Why is it so?" For a long time I was a pale shadow, perhaps for the first three years. In spite of the fact that this LJ nick existed since 2003, it gained some popularity in 2005. In 2005 I was invited to a TV programme about blogging on channel “Culture”. That moment my blog counted the first thousand comments...

Julia: At Halloween 2005 vero4ka wrote a post titled "Feel Bloginya": "Well, there are one thousand of us, my dear friends, it is similar to the club "Tochka" in Octyabrskaya St. plenty of people, who crowd at the bar, talk and squeeze through the crowd, shouting on the phone, waving to their friends and at this very moment I'm wstanding up wearing a skirt, I take carefully the microphone from the stand and say,

“Uh, I'm terribly happy, I'm serious. Welcome. Like Dr. Kurpatov would say, I recommend you stay with us".

Vera: That time I treated 1000 people as some unbelievable number. It was not clear for me why there were so many. I didn't do anything to be read. I didn't even had the Internet on my home computer till 2006. I used Internet cafes and Internet rooms at the Department of Journalism of MSU room 215. I vividly remember it now, there were eight computers occupied all the time, because Zasursky (the Dean of the department-T. Z.) decided to set free Internet for the students. There was a long queue in any class. No matter what class you decided to miss there was a crowd of people in the Internet room. (Idlis, 2010, pp. 223-224)

Vera (having a thousand fans): For me LJ is the longest project in my life, it was started when I was 16 and has been existing until present. I have no money from this project, no evident benefits, except some secondary ones, like a relative died and there is someone to say he is sorry. But no work, I was paid for or promised all the best conditions, lasted so long or was so interesting for me.(Idlis, 2010)

\subsubsection{Basic Components of the Worldview in Vera Polozkova's Early Work, Search of "Like-Minded People"}

Very curious facts we are interested in can be found in the book "Nepoemanie". The book was published simultaneously with "Photosynthesis" in 2008, but most of its poems are dated 2004-2005. The very title of the book on the one hand emphasizes isolation of the author's position (doomed to misunderstanding), and on the other hand reflects genre originality (not a poem, but something fundamentally different). Let's consider its contents in terms of its value in youth culture.

We have already mentioned that the main characteristic is the search of like-minded people. To my mind, this topic takes an essential part in Vera Polozkova's poems in 2003-2005. "A Letter to a Faraway Friend" (addressed to E. P. Chukovskaya) gives an ideal type of such relations: "We are incredibly close like rhymes which make a poem, like those soldiers, partisans who found in the forest their forces. Relation, tension, music mixture-it doesn't matter what we say..." ("Nepoemanie", 2014). Life outside this close relation is meaningless for the lyric heroine "Without you I'm dying from frost penetrating my soul" ("A Letter to a Faraway Friend", p.98). She is looking for it in relationships with her mother and in spite of family ties cannot find it "yes, we are good but we/ ruin each other,/ like two black Fatimas" ("Something Goes Wrong With One Of the Schemes...”, p. 71). She continues looking for it in relations with the men she loves and she gets disappointed again: "We need men to stick in their clavicular fossas and nothing else we need from them." ("On the Rock", p. 32), "Our men in fact are / to crumple a sleeve with bare hands/ (the profile is obscure: the morning is full of misprints)/ to cling, to frown and to get sober" ("Men", p. 48). Finally, she finds it in a creative artistic environment: "And I look fascinated and my heart knows no decay, while Sergey is singing softly, while Lena is laughing chatting, while they throw me a lifebelt from the scene-deck, I will overwinter..." ("Zdravnitsa", p. 147). Ever since "the only pronoun "we" has existed in her life and creative work. ("Last Summer Evening", p. 121). A range of poems presents a special atmosphere of friendly co-communication, when you may sit "shoulder to shoulder", "prolong September like warm rum and warm up quietly inside" ("Last Summer Evening”, p. 121). Among the "like-minded people" there are real people: Kostya Buzin ("We are a comic duet/ of a silly girl and a lasybone, I moving chapiteau, / extras, creative servants" ("Irregular Sonnet", p. 191); "Kostya, Olenka, British..." ("Or, for example", p 204), Sasha Manotzkov ("Sisters", p. 194)

Sincerely admiring friends ("There is something peculiar in all those boys with a husky voice, / cheesy bass, /and glossy hair,-Such men come and go away themselves/ and in the gaps become/ your greatest love... you beam so brightly that any display flickers. ... And you sing like announcers of extra-terrestrial TV news, / and people of Earth listen to you with their mouth open..." ("Or, For Example", p. 204). Polozkova mentions such typical subculture models of behavior as a tendency to epatage ("Well, we are too outrageous-if we don't like South Goa, then prefer to be imprisoned./ However, we seem to pass the same fate" ("Dot the I" p. 201); alcohol and drugs addiction ("Everyone drank 200 grams" ("Or, For Example", p. 204); "Kate is dead drunk and let it be forever..."; "Kate has a bottle of rum at home, and in the coat lining crazy hashish" ("Kate", p. 210)), use of slang (chants, ksiva, bluff and others) and obscene language (almamaterna, proeball, pizdetz, fucking spring, 
fucking squint, awful load of dungs, fuck you, damn princess and others) .

Goa Island, as the Mecca of the hippies is mentioned as a possible bad end of clubbers. For example, the heroine "has a dream about a homeless wearing an overcoat that is rotten to the third" ("Irregular Sonnet", p. 191).

The poetess confines that her friends-" "all of them are like a rabble: well educated and handsomely dressed, keen on jazz, very loud and drunk to death" (Life As It Goes, p. 130), but that is why she loves them: "I love them all for that..." (Life As It Goes, p. 130). And here is the phrase to summarize "We are gilded youth/ grown in the slums" ("Something Goes Wrong With One Of The Schemes...", p. 71).

\subsubsection{Basic Components of the Worldview in Vera's Early Work, Elitism}

Another characteristic of the world perception of youth subcultures is elitism understood as esoterism (belonging to a special community). I have already mentioned above that everyone who has written about Polozkova's personality and work marked her tendency to exclusivity. Julia Idlis says, "it is so easy to have your own opinion on the Internet: web irresponsibility allows share your opinion in any place, in any manner and at any time. It is even easier to be a little prince with his own baobab tree on a small planet in the infant Runet. However, vero $4 \mathrm{ka}$ is like a little prince both on the Web and outside it, she likes this role, which once became her trademark." (Idlis, 2010, p. 225)

The conscious wish of the poet to express her "Ego" in her poems is essentially important in this context and was declared in the conversation with Idlis:

Vera: I never lie. At one point all my thoughts were expressed in my LJ. When I began talking, I was told, "We have already read that, thank you." Or a guy saying something in a big company suddenly saw me and remarked, "Oh my God, I don't even want to think how my friend list will change tomorrow." There was time when I wrote everything in the LJ, till 2005, 2006, I guess.

If I talked to someone, I did it sincerely. If I write a text, anyway, I write it about myself. I'm not interested in anything else. Perhaps, everything will return and will be similar to what it was (Idlis, 2010, p. 240).

This attitude is presented in different ways:

—As direct dogmatic statements: "except us, elitists..." ("On the Rock", p. 32), "I can be rude and heavenly" ("Childish", p. 94); "The air is taken like absinth, it's rough and burns the nosel It costs a penny to us, young legends..." "and I really know how much I'm valued"("Let It Be So", p. 90); "And everyone is a bully, a demon, an urchin of heaven..." (Last Summer Evening, p. 121);

-As a proof by contradiction: "It's better to think you are a villain/ then think you are worse than a stub" ("Something goes wrong with one of the schemes..." p. 72); "if someone cuts the ground from under your feet, then learn to fly" ("To One Boy Not To Get Cold", p. 135);

-As a proud awareness of the youth and granted freedom, "I'm starting. I smell like a new open book" ("Games", p 81); "I want to be free/ to leave no marks" ("On the rock", p 30); "While I'm dancing, arguing, yelling... everything lives" ("Good, I say", p. 112); "Freedom is to be absolutely poor..." ("Freedom", p. 140);

-As a talk on equal terms with the iconic characters of Russian and world culture: "I'd better talk like Tiresias,..." ("A Letter To a Faraway Friend", p. 99); "We are going to the bus- stop like Pilat and Ha-Notzry..." ("One Morning", p. 101); "I'm Dorian Gray, I'm likely getting old..." ("November", p. 92); ("To reach Vladimir Mayakovsky I need five-six centimeters more" ("The First Heart-Rending Panic Every Morning”, p. 66);

-As a kind of duplicity (with elements of contrast, irony and mockery): The girl is a black comics, well phoenix,/ like a lifetime anecdote./ The girl is a black onyx, filthy broom, / she is both a poison and an antidote./ ...The girl is strange a bit, not a woman of fashion,// but an almighty man.( "As If", p. 150); "Vera has a character and a profile of rebel/ and flaming eyes and a great appetite" ("About Love", p. 148);

-Finally, as a desperate attempt to protect her own world from "theprudent coal of adult braziers":

"And for that, because I'm a puppy,

The Gods please me more than the others.

And for that I always act risking

I get immortality

On the prudent coal of adult braziers."

(“Answering machine”, p. 104) 


\subsubsection{Basic Components of the Worldview in Vera Polozkova's Early Work, Search of Love}

Love becomes the dominant value of all youth subcultures. T. B. Shchepanskaya marked in regards, "Perhaps, the central motive of the System discourse, its magic exercises, songs and graffiti is loneliness and search of love." (Shchepanskaya, 2004, p. 174); "Search of lovers is the meaning of all hangouts for a significant part of its participants." (Shchepanskaya, 2004, p. 177). At the same time sexual practices of youth subcultures on the one hand tend to disregard taboos of traditional culture and to reject its norms (Shchepanskaya, 2004, p. 81), on the other hand to a searching orientation, which causes a variety of sexual practices in qualitative and quantitative meanings" (Shchepanskaya 2004, p. 81). It should be noted that "asceticism, virginity, romantic love in this environment equal to group sex, change of partners and homosexuality (male and female)" (Shchepanskaya, 2004, p. 81).

The book by Vera Polozkova focuses on search and literary study of the nature and essence of love. In general, her deep and distinct description of love diversity is worth admiring:

Love / pain: "They gave me pain- exquisite style and quality" ("Pain", p. 21); "'I'm sick. I'm in grain. / My diagnosis is already a password. / Am I hopeless? Infected? Do not touch me —Lovepain ("Lovepain", p. 9); "...spontaneous, powerful, deathful virus, feverish pollen" ("Kamlat", p. 163);

Love / torture: "The day is like the rack: and we both stretched on it my memory and next to it me." (Lovepain, p. 11); "An eye of the day is a light trap" ("Lovepain", p. 13);

Love / competition: "The degree of estrangement is growing like gangrene and licks the feet, beware. Each bar we are going to, a siren is blowing and crunches a floor from the shells. Am I an enemy, to push gas to me? I'm not your enemy to you." "Close Battle", p. 173);

Love / jealousy/hatred: "Pray, so that she doesn't feel this hellish, desert, sharp and old man's, royal hatred to death; and then resignation, all of a sudden: "Oh my dear, my honey and so on. Take care of her calm."("A Two Minute Hatred", p. 149);

Love / obsession: And since then I've been a pale, crazy spammer, a rhyming thing, an obsessed hare, finding an epithet to a fox or bear. ("Nonsense", p. 165);

Love / death: Through you naughtily, uncomprehendingly/ frowning brows / A baby/ Death (“A Baby”, p 20); "We will never apart, perhap, / if I don't wake up one day all at once." ("Dreams", p 27); "You are a real poison / and my death moan" ("Sirens", p. 41);

Love / curse: "My damn lovepain..." ("Lovepain”, p. 13);

Love / despair: "Incurable despair, a greedy bullet, merciless death, faithful malady ..." ("Lovepain", p. 14); "...love is a wolf, melancholy capturer ..." ("Pshhh", p. 133);

Love / betrayal: "Love is like war/it is like a secret agency/ a betrayer is not disapproved/ but shot with a random bullet./ You risk yourself twice." "Special agents", p. 47)

Love is stronger than art: "I am much more desperate and pure with you" ("Wake up and feel hot and dense inside...", p. 82)

Love / enlightenment / the highest point of life: "Like with love: just in a second he is no one else. So that insides boil synchronously with eyebrows like an electric arc, so that you feel stronger and sharper under his bitter eye." ("A big poem", p. 106)

Love / understanding everything/ forgiving everybody: "How many women will breath you, spoiling their lungs/ and nobody will love you like me ... Measure days from you up to you... How many women will lull you, bastard. I and such lulls will sing only to you. ... Tumble hair, adjust a collar. ... I'm still waiting when you'll let me go. I'm still waiting when you'll forgive me."(“A fringe”, p. 155)

Erotic motives are essentially significant in Polozkova's poems. She willingly and joyfully emphasizes sexuality of her lyrical heroine: "I've got a honey coloured breast and / And sandalwood eyes" ("On the Rock", p. 32); "Here Caucasians always say/ That they want to meet me one day." ("On the Rock", p. 31); "Arabians all smile at her, I Like Hugo Chaves and strangely tut with the tongues." ("While he is getting up from the bed...", p. 158).

J. Idlis noted in her article that once Polozkova was mostly criticized for showing off at the interview: "For me, $a$ representative of the generation, a family is a depreciated notion. I don't know any happy family. I don't know a union which would last more than five years and wouldn't ruin the members. We are not used to taking care of anybody else (Idlis, 2010, p. 237). Some time later there was another statement: "I don't believe in a happy marriage... That's why I would like to be emotionally free. I don't want to put a great deal of trust in anyone. I 
would like to learn to expect nothing from people. And I need a baby, and I'll have one, by all means. But I'm not sure if there will be a man with me. It will be great if there is some. But if there is no one, I won't be upset. I will find what to do." (Idlis, 2010, p. 237). There are some frankly shocking statements:

Julia: What are your ambitions? What will you look like at 40?

Vera: (smiling): Well, reserved, with a short haircut ... bisexual, perhaps... a wiry, energetic lesbian at her fifties with sharp eyes and an ironic mouth, short half grey haircut, probably, I'll frown my eyebrows sarcastically and talk through delicious smoke of a roll-up cigarette. (Idlis, 2010, p. 247)

Searching orientation of partners' relationships is partially represented in her early lyrics: “...wine doesn't cure and the mother is crying. / Sex means nothing and the boss is bugging" ("DiskWorld", p. 76); "I enjoy being part of a couple. / I like it more than to be alone" ("Special Agents, p. 47"); "When you lose integrity / You madly want to have a baby" ("To be Continued", p. 110); "I fancy: a child's running in a hotel; a shadow, curtains, happiness there." ("A Letter to a Faraway Friend", p. 98); "If I fell in love with her all of a sudden, it will be my fault" ("Little Rock-and-roll”, p. 75).

Thus, Polozkova starts literary study of the nature and essence of love with very personal things (the series "Lovepain" is like a sense biography), then with an attempt to release from a love trap with new love, posts on the Web, comprehension of poet's purpose, new fancies (we see an image of a young man) (the series "Simeiz"). Finally, the last poem of the book represents poetic recognition as the biggest happiness. It is difficult to assume if such ending really reveals her deep developing feelings or it is conscious systematization of the poems, as the book appeared later (2008).

\subsubsection{Basic Components of the Worldview in Vera Polozkova's Early Work, Search for God}

Existential constructions of the young poetess are of interest as well. T.B. Shchepanskaya noted that youth subcultures have "ethnic, religious, political symbols taken from various sources which <obviously> changed their original meaning" (Shchepanskaya, 2004, p. 234). In order to understand their meaning and functions it is necessary to keep in mind the original rebelling character of youth movements. For example, "in the period of atheism the underground turns to God" (Shchepanskaya, 2004, p. 121). However, as soon as "a social institution" (in this case it is orthodoxy T.Z.) sets in, the underground looks for alternative religions (Shchepanskaya, 2004, p. 122). To my mind, Polozkova's attitude to God correlates with subcultural ideas, it is really search for "her own God": “... unbearable lightness - the old God / is overthrown, another is not chosen, you are somewhere in between." (Shamel-Sheikh, p. 159)

At the same time this topic appears in the determined discourse, as a rule, on reflection:

About the meaning of life: "Everything sounds and lives for you, this is the point / and the God breathes life into your ear." ("A Letter to Kostya Busin to the next house", p. 189);

About poetic gift: "We spent thousands not pennies of / Divine, gentle poetic gift... " ("Bankers", p. 16); "I was gifted a lot, my God, it's high time to pay the loans";

About love: "The Highest wanted to amuse/ and to test me and you... " ("Joker", p. 15); “...don't forget to pack the God into the suit-case./To be able to pray for you anywhere else" ("Further", p. 29)

About time: "Time with a whip, that rides herd" ("Chronophobia", p. 142); "Four centuries pass a day ..." ("The Sun", p. 25); "Time passes fast, crumple faces its feet / singing wildly like the Roc" (“As If", p. 151).

The God in Polozkova's lyrics is on the one hand "The Almighty power engineer", "The Almighty demiurge", creator of "the lace invention". This is he "in the pale moonlight penetrating the window, with a small orbit satellite / ...makes the movie about us ..." ("In the Pale Moonlight ...", p. 78). This is he who "clenched the world in his almighty hand", plays huge bowling with it. ("Good, I say", p. 112). On the other hand, the poet has peculiar trusting relations: "I dance for you, laugh, as the girl of Picasso breathe ... And while I'm dancing, arguing, yelling... everything lives" ("Good, I Say”, p. 112).

We can suppose that Polozkova like many other representatives of youth subcultures is keen on Eastern religious trends. At least in her early works we may see popular today motives of "transmigration of souls": "He will put us on spits/ rotate, roast and take through years, / set to the bodies where we'll stay/ till the God ejects us nowhere" "'As If", p. 151). At the same time the poet expresses doubts on this point: "This is your last life, don't lie to yourself. ... This is your last body, a strong skeleton. / Airport lounge before the departure to mountains. / wait a bit, girl, for a couple of years,/ and you'll laugh with the Highest.” (“A Fringe”, p. 155).

From time to time Polozkova refers to the topic of suicide and death like other subcultural authors. ("Why not asking: are you always eager to die?" ("Where is your happiness", p. 178); “... and we won't, we will go away 
seeking sense along a yellow brick road." ("A Letter to Kostya Busin to the Next House", pp. 188-189))

\subsubsection{Basic Components of the Worldview in Vera Polozkova's Early Work, Urbanism}

Youth subcultures are fundamentally urban. Vera is an urban poet as well. She illustrates either city landscapes (in different seasons and time intervals) or marine landscapes (mainly resort landscapes, and it turns out that they are urban). On the whole, she has splendid sketches of urban space. From my point of view, she is not inferior to V. Mayakovsky in the immensity of landscape reproduction and author expressiveness. For example, describing St. Petersburg: "There are columns like pastry caps", ("St. Petersburg", p. 23); "The sky is worn out, sags / cover with its belly pieces of large empires." ("Felt", p. 34); "The city wears numerous towers in the head with dirty grey hair./ and hums with displeasure..." ("One Morning", p. 101); "Touch the post at the bus stop, as if you touch the axis of the Earth" ("One Morning", p. 101).

\subsubsection{Basic Components of the Worldview in Vera Polozkova's Early Work, Social Motives}

In regard to social problems, Polozkova does not present them separately, they appear spontaneously and more often in reflections on the nature of poetry. For example, her heroine emphatically rejecting political spin "doesn't smoke grass or drink Vodkas" and "is already aware how much she is valued" ("Let It Be So", p. 90). Or in a well-known Russian poetic tradition contradicting the author and the crowd: "Two nations: families of ridiculous wimps... / and the madmen... / As for me, I'm drinking coffee in the café "Jennet Koshesy", / That was made by the waitress Saide..." ("On the Rock", p. 30); "It is scary not to live till that fan-bullet, / fatal overdose, brakes which are out of order. / That is all people need to say "Hallelujiah", / To repent, perceive, light the altars/ ... While you are alive you're a victim, gloomy elderly clown: / To point fingers, make faces, wrinkle nose / and once be ridiculed..." ("Gumilyov Updated", p. 152).

\section{Conclusion}

It goes without saying that Vera Polozkova's early work does not fit entirely in the frames of youth culture, it has much broader thematic range and traditions (this question can be the subject of a separate research), methods, literary integrity and value. No doubt, Vera Polozkova has become a bright exponent of the tendencies relevant to youth subculture. They are expressed in the motives of search of "like-minded people", poetization of their images and models of behavior, the heroine's strive for freedom, approval of marriage search, philosophical eclecticism, literary exploration of the city space, ultimate expressionism, as well as in mentioning some genres of youth cultures, use of youth slang and numerous obscene words (work with precedent texts). The poet widely uses information and communication technologies, in particular Polozkova is a well-known blogger so-called "multithousand". The analysis show that these particular facts allowed Polozkova to go out of the web space and start a dynamic and successful activity on the stage and in the theatre.

\section{References}

Buksha, K. (2014). Ksenia Buksha writes in her LJ. Retrieved from http://encvera-polozkova.ru/other/kseniya-buksha-pishet-v-svoyom-zhzh

Bykov, D. (2009). Not Little Vera. Retrieved from http://encvera_polozkova.ru/other/nemalenkaya-vera

Chernyak, V. D., \& Chernyak, M. A. (2010). Network Literature. Basic principles of mass literature: Educational dictionary and reference book (p. 167). St. Petersburg: RSPU named after A. I. Gertzen.

Desyaterik, D. (2014). Network Literature-Alternative culture. In Encyclopedia. Retrieved from http://enc-dic.com/altcult/Seteratura-12.html

Gutrina, L. D. (2012). "Social Circle" as a Value of Modern Popular Poetry. In Cultural goods-XXI: revision of values 9mas culture and its consumers: Collective monograph (pp. 172-180). Yekaterinburg: "Azhur".

Idlis, J. (2010). Runet: Created idols. Moscow: Alpina non-fiction.

Kravchuk, D. (2014). TV channel "Culture”. Retrieved from http://enctvkultura.ru/anons/show/episode/ id/63145/brand/20905/

Manin, D. (2014). Instead of Manifesto. Retrieved from http://www.netslova.ru/teoriya/seteratura.html

Nekludov, S. J. (2002). Folklore: Typological and Communicative Aspects (Vol. 3, pp. 3-8).Traditional culture.

Polozkova, V. (2014). Hereinafter citation of publication. In Nepoemanie (p. 224). Moscow: Livebook.

Shchepanskaya, T. B. (2004). The System: Texts and Traditions of the Subculture (p. 286). Moscow: OGI.

The Literary Newspaper. (2009). Retrieved from http://encold.lgz.ru/article/10130

Zolotova, T. A. (2014). Verbal Creative Work of Youth Communities. In World classics and youth culture: 
Materials of All-Russian scientific and practical conference with international participation (pp. 21-28). Yoshkar-Ola: Mari State University.

Zolotova, T. A., \& Efimova, N. I. (2014). Folkloric narratives in modern youth culture (on verbal creative work of youth communities in Mari El Republic). Life Science Journal, 5, 532-535.

Zolotova, T. A., Efimova, N. I., \& Sitnova, A. A. (2010). Verbal Creative Work of Youth Communities in Modern Culture. In The materials of All-Russian congress of folklorists. Collection of reports (pp. 31-40). T. I. Moscow: State National Center of Russian Folklore.

\section{Copyrights}

Copyright for this article is retained by the author(s), with first publication rights granted to the journal.

This is an open-access article distributed under the terms and conditions of the Creative Commons Attribution license (http://creativecommons.org/licenses/by/3.0/). 